\title{
Learning to Pull the Strings after Suez: Macmillan's \\ Management of the Eisenhower Administration \\ during the Intervention in Jordan, 1958
}

\section{Louise Kettle}

\begin{abstract}
This analysis re-instates the importance of the 1958 British intervention in Jordan within the study of Anglo-American relations and the revisionist literature on Suez. It does so by challenging the idea of British subservience to American foreign policy after the 1956 crisis, and it reveals two key lessons learnt by London: that Britain's economy, power, and influence were in decline and that Britain could no longer intervene in the Middle East without American support. Having learnt these lessons, Prime Minister Harold Macmillan proved to be a shrewd political actor who used the opportunity of the Jordan intervention to turn the policy of the Dwight Eisenhower Administration to British ends, regaining Britain's maximum power and prestige for the minimum loss of resources.
\end{abstract}

Historians have widely concluded that the 1956 Suez crisis was a watershed moment for both British foreign policy and Anglo-American relations. ${ }^{1}$ In foreign policy terms, the events heralded the end of Britain's "moment" in the Middle East that signalled the beginning of a 
change in the dynamics of the region as Britain shifted from a role as an Imperial Power to one of junior partner to the United States. ${ }^{2}$ For the "special relationship", the events rocked relations on both sides of the Atlantic: American diplomatic and economic pressures eventually forced the humiliating British withdrawal from Egypt. Immediately after the events, the State Department official in charge of Britain declared that the effect of Suez on Anglo-American relations "has been the rupture of the fabric of mutual confidence upon which the alliance rests." ${ }^{3}$ Harold Macmillan, who succeeded Anthony Eden as British prime minister in January 1957, noted in his diaries, "There was an equal sense of disillusionment on both sides. It seemed as if the long tradition of close co-operation which had been brought to such a high degree of confidence and respect was now seriously, if not fatally damaged."4

Yet, in contrast to the premierships of his Conservative predecessor, Eden, and Labour successor, Harold Wilson, Macmillan's time as prime minister has been acclaimed as the "golden days" of the trans-Atlantic alliance. ${ }^{5}$ This result was surprising as Macmillan, Eden's chancellor of the Exchequer during the Suez crisis, had on-going feelings of resentment towards the Administration of President Dwight Eisenhower. He later recalled in his diary that he felt American handling of Suez had been "almost hysterical outbursts". 6 Early drafts of his memoirs also pejoratively referred to Eisenhower and his secretary of state, John Foster Dulles, as "inept" and "emotional and vindictive" over the events. However, Macmillan had learnt that he needed American support for the future. He noted the difficulty and importance of regaining the relationship in his memoirs:

How were we to treat the United States, and to re-establish that alliance which I knew to be essential in the modern world? Nor would it be worth arguing whose fault it 
was. Somehow, without loss of dignity and as rapidly as possible, our relationships must be restored. ${ }^{8}$

Consequently, he worked to develop a new closeness between Washington and London that would last from Eisenhower to the presidency of his successor, John F Kennedy. ${ }^{9}$

The argument exists that the compromise for the renewed relationship after Suez was British subservience to American policy. ${ }^{10}$ In contrast, another posits that Britain defended its regional interests against the Americans throughout the 1960 s and beyond. ${ }^{11}$ Still another stresses on-going confrontations between the allies regarding policy in the Middle East. ${ }^{12}$ The events surrounding the 1958 intervention in Jordan are crucial within this debate. ${ }^{13}$ The military operation, "Operation Fortitude", was Britain's first new intervention in the region after the disaster of Suez and was thus risky and controversial. ${ }^{14}$ Even Macmillan described the proposed operation to the Cabinet as a "quixotic undertaking". ${ }^{15}$ However, the operation is most significant for revealing in microcosm a prime minister determined to keep control of the situation, pulling strings from behind the curtain to engage and manage the Eisenhower Administration in a way that would protect British interests with the use of American assets. Macmillan was shrewd, pragmatic, and determined to get American political, diplomatic, military, and economic support for Britain's return to the region, allowing Britain to regain maximum prestige and power with the minimum risk and loss of resources. For this reason, British intervention in Jordan in 1958 is a crucial, yet under-appreciated, event in the study of Anglo-American relations and British foreign policy in the Middle East. The study of this operation not only challenges existing ideas about the post-Suez relationship and reveals Macmillan's approach and skill in handling the lessons of Suez. It also provides the first example of the lesson that remains firmly within all British foreign policy and military 
planning today: all British interventions in the Middle East should take place with American support. As Macmillan declared on the eve of the landings in Jordan "We would rather be wrong together than right separately". ${ }^{16}$

Following the disastrous Suez affair, there was a great clamour to draw lessons from the events to inform the handling of crises in the future. Presumably, to avoid any investigation that may have revealed the Anglo-French-Israeli collusion over Suez, the government refused to hold any public or parliamentary committee-based lesson learning enquiries. ${ }^{17}$ Official histories proposed by the Foreign Office and the suggestion of the publication of "Lessons Learned" reports by the Ministry of Defence were also vetoed. ${ }^{18}$

Despite government protestation, some learning occurred within Whitehall evidenced through reflections recorded in reports, assessments, meeting minutes, conference notes, and despatches. ${ }^{19}$ These included the "Lessons Learned" despatch prepared by the commanderin-chief of the Allied Forces during the Suez campaign, Sir Charles Keightley. In explaining the increasing importance of world opinion as a principle of war, he concluded that the actions of the United States prevented the British military from obtaining their objective. ${ }^{20}$ For him, the key lesson to ensure future operational success was to work with the United States:

This situation with the United States must at all costs be prevented from arising again. Conversely a united Anglo-American position would have assured a complete success of all our political objects with the minimum military effort. The achievement of this is a political matter but the effects on military operations are vital. ${ }^{21}$ 
The Chiefs of Staff circulated and discussed Keightley's report in detail. ${ }^{22}$ Macmillan also read it; and he had a violent reaction to the Ministry of Defence proposal to publish the despatch. $^{23}$

At the same time, Sir Guy Millard, who served as both Eden and Macmillan's private secretary for foreign affairs, produced another lesson-learning document. ${ }^{24}$ His paper focused on recording an account of the events of Suez from a British perspective and identifying some lessons for the future. It concluded: "For Britain, Suez was a climacteric. It had severely shaken the basis of Anglo-American relations and exposed the limitations of our strength. This fact defined the conditions within which British foreign policy must henceforth operate." ${ }^{25}$ For Millard, there were two clear lessons for the future:

We could never again resort to military action, outside British territories, without at least American acquiescence. Our capacity to act independently had been seen to be closely circumscribed by economic weakness. The experience of Suez may have led to a re-assessment of British interests and of our relative position in the world. ${ }^{26}$

These were strong but insightful words, which recognised the future importance of working with the Americans and a new understanding about Britain's position in the world, an awareness of which had begun to echo elsewhere in government.

Nine months earlier, Eden had offered similar reflections upon the lessons of Suez, which he had sent to the Foreign Office. At the end of five pages of manuscript notes, he concluded that Suez had forced a reassessment of Britain's place in the world and its international relationships. Eden wrote, "The conclusion of all this is surely that we must review our world position and our domestic capacity more searchingly in the light of the Suez experience, which has not so much changed our fortunes but revealed our realities". ${ }^{27}$ 
The questioning of Britain's international position had also led the government's Foreign Affairs Steering Committee to reconsider "British Obligations Overseas". ${ }^{28}$ The resulting paper, produced in April 1958, reported that Britain had two endeavours: first, to maintain world peace, order, and essential interests overseas and, second, improve Britain's economic position. There were five aims to achieve the first objective, two of which would become particularly relevant in the summer of the same year: "to maintain a large measure of identity between British and American interests" and "to maintain political conditions favourable to our trading requirements throughout the world, and especially in the Middle East." ${ }^{29}$

However, the paper also concluded that Britain had a number of problems in the Middle East that were proving challenging to obtaining favourable conditions including the rise of radical nationalism, the relic of colonialism, and a divergence of interests between Britain and the oil producing and transit states. Furthermore, attacks on colonial, strategic, and commercial interests had become difficult to prevent as the cost of conquering and occupying a territory was no longer economically viable. The stark conclusion reached by the Committee was, "We are no longer in a position to 'go it alone", $\cdot{ }^{30}$ Instead, Britain's could only achieve its objectives by working with the Americans: "promoting United States involvement and the harmonisation of the Anglo-American policy". ${ }^{31}$

The Conservative Party had also reached the same conclusion. On 9 July 1958, five days before the Jordan crisis began, the Conservative Parliamentary Foreign Affairs Committee considered the issue of the Middle East and, more specifically, intervention in Lebanon. During the course of the discussion, one member, Nigel Nicolson, remarked that he did not think that an intervention in Lebanon would have any parallels with the Suez 
operation "if only because the lesson of Suez was that we must have American (and if possible Iraqi) support. These we had in respect to Lebanon." 32

These various reports reveal that Suez produced two key lessons learnt: that Britain's economy, power, and influence were in decline and that Britain could never again intervene in the Middle East without American support. They also demonstrate that these lessons remained clearly identified in a number of different institutions, fora, and documents with which Macmillan would have been connected. It is clear that they had become important ideas across government within the military, the Cabinet, the Prime Minister's Office, the Foreign Office, and the Conservative Party. It would also soon become clear, by Macmillan's actions, that he had learnt the same lessons and intended to re-build the Anglo-American relationship as soon as possible to influence American policy in ways that would help him to manage Britain's inevitable decline but with the minimal loss of interests.

In fact, Macmillan had long held convictions about the potential for Britain to manipulate the Americans in a "Machiavellian fashion". ${ }^{33}$ Meeting Macmillan at Allied Force Head Quarters during the Second World War, Richard Crossman, the head of the German section of the Political Warfare Executive, recalled an analogy made by the future prime minister of the Americans as akin to the Romans and the British to the Greeks. For Macmillan, the British were culturally and intellectually superior to the Americans, as the Greeks had been to the Romans, and could use this advantage to manage their United States counterparts. ${ }^{34}$ Similar ideas had also informed the Labour government during 1945-1951, whilst Eden had later explicitly examined a strategy of "power by proxy" through the Americans. ${ }^{35}$ These ideas continued into Macmillan's premiership and proved vital in the handling of the Jordan crisis. 
Even before his succession to the premiership, Macmillan had been quick to try to repair the Anglo-American relationship resulting from Suez. After a North Atlantic Treaty Organisation meeting in Paris on 12 December 1956, he took the opportunity to visit Dulles to speak to him in confidence and begin to smooth over the situation. During the course of their conversation, he indicated that he had disagreed with Eden's decisions over Suez, particularly regarding the United States, and revealed that he was hoping for a government shift to lead him or Richard Butler, the Conservative leader of the House of Commons, to the premiership. $^{36}$

As soon as Macmillan became prime minister, he and his foreign secretary, John Selwyn Lloyd, gave priority to Washington. With British interests in mind, they immediately looked to develop a working partnership for the Middle East. In January 1957, Macmillan sent an invitation to Eisenhower to meet, work to improve the Anglo-American alliance, and publicly demonstrate Anglo-American friendship. ${ }^{37}$ That Macmillan was the instigator of these events was significant. During the Second World War, he had witnessed first-hand at the January 1943 Casablanca conference the relationship between Prime Minister Winston Churchill and President Franklin Roosevelt; he was deeply impressed at how the two leaders worked together. Like Churchill, he had an American mother - a connexion that could be emphasised - and, most significantly, he already had an established relationship with Eisenhower to draw upon and use to his advantage. During the Second World War, Eisenhower and Macmillan served together in North Africa: Eisenhower as the supreme commander of the Allied forces in Europe and Macmillan as Eisenhower's British political advisor. 
The result of Macmillan's invitation was the Bermuda conference held in March 1957, which, amongst other issues, saw discussions about the Middle East and revealed that the United States was equally keen to restore working relations in the region. ${ }^{38}$ A State Department position paper for the conference stressed the importance of maintaining the British as a Middle Eastern ally with an aim to develop "mutually consistent policies" ${ }^{39}$ At the conference, any discussion of Suez proved still to be too raw - Eisenhower noted in his memoirs that he and Dulles "found it difficult to talk constructively with our British colleagues about Suez because of blinding bitterness they felt". ${ }^{40}$ Nonetheless, both Macmillan and Eisenhower sought to reassure each other of their positions. Macmillan declared that the British were "committed to stay in the game and cooperate with the United States", whilst Eisenhower advised the British that he wanted to "build them up again in the Middle East". ${ }^{41}$

Following the Bermuda conference, Macmillan pushed for an additional meeting to strengthen the re-building relationship. Another conference was organised later in the same year at Washington. The American ambassador to Canada, Livingston Merchant, wisely noted in a memorandum to Dulles: "I think that the request by Mr. Macmillan for the meeting constitutes a supreme effort by the British to regain their war-time position of exclusive and equal partnership with the U.S. ${ }^{, 42}$ Nonetheless, Washington was equally keen to re-build the relationship and, in a conversation with Selwyn Lloyd, Dulles stated his hope that the conference would "mark the beginning of a new and closer phase in Anglo-American relations". ${ }^{43}$

Again, the Washington conference saw discussion of Middle Eastern issues where the prime minister sought further to institutionalise Anglo-American co-operation. ${ }^{44}$ As a result, 
several joint working groups emerged to produce co-ordinated planning and policy approaches. ${ }^{45}$ For Macmillan, this process revealed a success in his efforts to a renewed relationship, and he declared to the Cabinet, "The prevailing mood in Washington had therefore been favourable to proposals for closer Anglo-American co-operation". 46 One working group was set-up to focus on Lebanon. Over time, Macmillan had become keen to find an opportunity to return to the Middle East region and reassert British power; but having learnt the lesson of Suez, he wanted this result to be achieved having British forces stand side-by-side with American soldiers in a strong demonstration of renewed trans-Atlantic unity. By November 1957, his attention had begun to focus upon pro-active joint military planning for intervention in Lebanon and Jordan in the event of a coup there. ${ }^{47}$ The British Cabinet had already tentatively decided that if the Lebanese president, Camille Chamoun, requested military intervention, "the United Kingdom should respond favourably, if the United States agreed." As a result, the British and Americans developed contingency plans: “Operation Shamrock" succeeded by "Operation Bluebat". 48

However, during this contingency planning for Lebanon, Macmillan placed more and more emphasis on joint intervention to accelerate and institutionalise re-building the AngloAmerican relationship. This emphasis went too far too quickly, and the Eisenhower Administration soon felt that the British were becoming overly hawkish, moving planning from contingency to immediate intervention. Dulles advised the British ambassador, Harold Caccia, "some of our people, not just in Washington but elsewhere, had the impression that we were being crowded by our British colleagues into intervention in Lebanon". ${ }^{49}$ In fact, the Americans felt that they had to "cool down the British and their enthusiasm for immediate action", ${ }^{50}$ especially as there were remaining concerns within the Administration about 
establishing too close a military association with a former Imperial Power. ${ }^{51}$ The Americans became suspicious about London's intentions and nervous about their implications. By June 1958, United States policy on joint intervention seemed to have shifted irrevocably. A special National Intelligence Estimate focused on the possible consequences of United States action in Lebanon and concluded, under the heading "Effect of UK Participation": "We believe that [an] adverse reaction would be intensified if the UK participated. ${ }^{, 52}$

The British seemed unaware of this change in policy. However, the Foreign Office and Chiefs of Staff sensed a retreating commitment on the part of the Americans to joint planning. The principal private secretary to Selwyn Lloyd, Denis Laskey, complained of "dilatoriness" in American Middle East policy, and Caccia agreed that the Americans had been "rather slack" in committing to concrete contingency plans. ${ }^{53}$ Nonetheless, a new opportunity soon emerged for Macmillan to manage the return of British troops to the Middle East to protect British interests. He was determined to maximise this opportunity to achieve his long-standing objectives informed by the lessons of Suez.

In February 1958, Syria and Egypt merged to become the United Arab Republic [UAR] with Abdel Gamal Nasser, the Egyptian president, as its leader, thus increasing his power and influence as well as that of his Soviet supporters. Less than two weeks later, to balance Nasser and the UAR, the Hashemite monarchies and Western allies, Iraq and Jordan, formed the Arab Union, igniting an intense propaganda battle between the two new polities. ${ }^{54}$ On 14 July 1958, the Iraqi monarchy, which had been installed by Britain upon the founding of Iraq in 1922, was unexpectedly overthrown in a bloody coup d'état. An Arab nationalist group, the Free Officers led by Brigadier Abd al-Karim Qasim, murdered King Faisal II, the Regent and Crown Prince, Abd al-Ilah, and the premier, Nuri al-Said. News of the coup 
reached London through American intelligence, reporting the overrunning of the British Embassy in Baghdad and its setting on fire; there was immediate suspicion of Nasser's involvement. $^{55}$ The coup had a substantial ripple effect in the region: a Western ally, the Arab Union, had effectively dissolved; the 1955 Baghdad Pact - the British-led regional defence agreement aimed at preventing Soviet Russian influence in the region - was threatened; and the visible rising tide of Arab nationalism left many Middle Eastern leaders nervous over their own positions. Chamoun immediately called on the American and British ambassadors to request a military intervention to defend against a similar fate in Lebanon.

Despite the contingency planning for intervention in Lebanon, and the previous British desire to push for a joint intervention in the country, there was concern amongst the Cabinet that a similar request from Jordan may not be far behind. There were also concerns over the security of Kuwait and question of whether intervention in Iraq was a possibility all of which were areas where British interests were described as "paramount" in comparison to Lebanon. The Cabinet therefore concluded that although any action in response to the request had to occur as part of an Anglo-American plan, it was prudent to allow the Americans to take the lead in Lebanon with only "a small token British contribution". This action would achieve two objectives: visibility of a joint intervention whilst retaining sufficient troops to take the initiative elsewhere in the region. ${ }^{56}$

However, Eisenhower had different ideas and opposed any participation by British troops, even a symbolic force. ${ }^{57}$ Instead, he wanted to act unilaterally, setting aside previously discussed contingency plans to avoid the appearance of protecting colonial interests and negate the opportunity for the French to demand inclusion. As Macmillan noted in his memoirs, this time it was the Americans who would "go it alone": "This was indeed a 
strange reversal of the situation only eighteen months before." ${ }^{, 58}$ In fact, he declared that American actions were "a recantation - an act of penitence - unparalleled in history."59 However, Suez tensions must have eased since Bermuda as when Eisenhower telephoned Downing Street to inform it of his decision, Macmillan joked, "You are doing a Suez on me". 60

Fortunately for the prime minister, another opportunity quickly presented itself. Whilst Eisenhower was making his decision on Lebanon, a second request arrived from King Hussein of Jordan for an assurance that he would also receive military support if required. ${ }^{61}$ There had also been a contingency plan in place to support Jordan, "Operation Broil", and the Cabinet Defence Committee had begun to prepare urgent plans for sending troops to Jordan as soon as the news of the Iraqi coup reached London. ${ }^{62}$ The Committee preemptively considered the military implications of an intervention in Jordan the following day. ${ }^{63}$ The Foreign Office received immediate instructions to begin working with the State Department to recommend wording to King Hussein for a formal appeal for military assistance should it be required. The aim was to ensure an appeal written satisfactorily to persuade both the public and the United Nations [UN] that any intervention was legitimate under international law, despite the lack of a UN resolution. ${ }^{64}$

Macmillan also seized the opportunity and hawkishly asked Eisenhower what forces he would make available to any such request from the King Hussein-and urged a commitment for a "joint intention". ${ }^{65}$ Speaking to Eisenhower by telephone on 14 July - in a conversation where he repeatedly drew upon his personal relationship, referring to the president as "dear friend" three times - he emphasised, "we have got to see it together, dear friend" and "as long as I understand we are in this together. We are doing this together."66 
This emphasis was not lost on Eisenhower who noted in his memoirs, "He was anxious . . . he wanted my assurances that we were in this together, all the way.",67

The replies from Washington were slow, which troubled Macmillan. Whilst Eisenhower did not directly reply to Macmillan's telegrams, there were also concerns that Dulles was hesitant about a Jordan mission. ${ }^{68}$ In fact, this proved to be true; Dulles was sceptical about what could be achieved in Jordan, worrying that an intervention would weaken King Hussein's position in the long-term. ${ }^{69} \mathrm{He}$ also had suspicions about British motives as well as the necessity and desirability of the intervention. ${ }^{70}$

To counteract the slow progress, Macmillan quickly despatched Selwyn Lloyd to Washington with the aim of securing as much support as possible from the Eisenhower Administration for intervention and taking the added precaution of monitoring American public reaction. ${ }^{71}$ However, whilst Selwyn Lloyd was enroute, on the evening of 16 July, the formal request for assistance arrived. Having learnt the lesson from Suez, Macmillan refused to provide any commitment to King Hussein until he had received approval for British intervention from Eisenhower. Pragmatically, he was also particularly concerned that United States forces in Lebanon might withdraw, leaving Britain alone in the region to deal with Jordan and Iraq. He later concluded, "Nothing could be worse for our position in the Middle East than to find ourselves exposed and then abandoned". ${ }^{72}$ As a result, according to notes taken from a meeting with the minister of defence and Chiefs of Staff on whether to provide military assistance to Jordan, the first consideration was "the reply from President Eisenhower", 73

Macmillan immediately called a Cabinet meeting, which lasted three hours. During the course of the meeting, he phoned Dulles twice to gain support and confirm his position. 
Again the prime minister did not receive the answer for which he was hoping. In the first call, he consulted with Dulles over the British course of action and stressed the desire for American support:

M [Macmillan] asked if they should send their people in. The Sec [Dulles] said not tonight. M said we want to do it together. The Sec said we told Congress Tuesday nothing beyond what was explained to them would be done and we can't alter without consultation. $\mathrm{M}$ is unhappy doing it alone tonight - we may get separated when we are beautifully together. The Sec said we can make clear verbally our approval but can't do more. $^{74}$

Macmillan had succeeded in securing political and moral support but was looking for something more substantial, particularly American boots on the ground. In the second conversation, 90 minutes later, Macmillan had specific questions: Would the United States give Britain moral support? Would it provide an air demonstration? Would it provide logistical support and, perhaps later, men $?^{75}$ The American record of the conversation also states a request for providing support in the UN. ${ }^{76}$ The response was reserved but positive. The follow-up telegram from Lord Hood, minister at the Washington Embassy, confirmed that the Eisenhower Administration would not respond to the request from Hussein due to Congressional restraints, but it would provide a demonstration flight of aircraft over Lebanon, Israel, and Jordan. In addition, Dulles agreed that if Britain did send troops, the action would have his support. ${ }^{77}$ Following this reassurance, Macmillan advised King Hussein about the granting of his request for military assistance. ${ }^{78}$ He also felt the need to emphasise that this decision had occurred in consultation with the Americans. 
Once the operation in Jordan began, the need for including the United States became a combination of intention and pragmatic necessity, and Macmillan worked hard to manage the Americans throughout. On 17 July 1958, the 16 Independent Parachute Brigade flew from Cyprus to Jordan, with the Guards Brigade on standby to follow. The flight required overflying Israeli territory, and Selwyn Lloyd received instructions on 14 July to consider how to obtain the permission of the Israeli government to do so. ${ }^{79}$ However, seeking permission had not occurred because of the confusion of Selwyn Lloyd travelling to Washington and Macmillan leaving the launch of operations in the early hours of the morning to the Cabinet secretary, Norman Brook. As a result, when the Israelis discovered that British air transport had violated their airspace, the British airplanes received orders to land with some aircraft fired upon by anti-aircraft batteries. ${ }^{80}$

The Israelis had also learnt from Suez the importance of securing American support. David Ben Gurion, the Israeli prime minister, advised the American ambassador that Israel would not grant the British permission for overflying until Washington gave assurances of aid to Israel if it became the subject of retaliation from other Powers. ${ }^{81}$ At the same time as Ben Gurion negotiated with the Americans, Brook was trying desperately to remedy the situation from London. Receiving no reply from Israel, he reached out to Washington and requested diplomatic support. ${ }^{82}$ In a similar vein to Macmillan, Ben Gurion only conceded overflying approval after waking Dulles at 2:30 am to receive a personal reassurance of support. $^{83}$

Despite granting permission, Ben Gurion's actions were domestically unpopular and he soon came under heavy Soviet pressure to renege on the agreement. Two days after the start of the operation, Selwyn Lloyd reported that the Israelis were making overflying 
difficult and again put pressure on Washington for diplomatic assistance. ${ }^{84}$ The next day Macmillan received a message from the Israeli government to stop all overflying forthwith. ${ }^{85}$ Although not amounting to a formal withdrawal of permission, it presented the British with a serious problem: there was no immediate alternative to overflying Israeli territory and the British forces at Amman were reliant on air transport for circa 100 tons a day of food, stores, and ammunition. ${ }^{86}$ The solution, according to the Cabinet Defence Committee, was to convince the Americans to provide the entirety of the supply themselves, especially since they were successfully over-flying Israel to provide provisions to their own troops in Lebanon. This would not only solve the problem at hand but would also result in engaging the Americans in the joint action that Macmillan had long since desired: "Equally, there would be great advantage in persuading the United States Government to accept the responsibility of organising the transport column from Aqaba to Amman and generally cooperating with us. ${ }^{\prime 87}$ In fact, an early planning note passed to the deputy chief of staff had explicitly stated that this was an aim: "For political reasons we are anxious to involve the US in Jordan. As they may not agree to stationing troops we feel that they should participate in the airlift". ${ }^{88}$

By 22 July, the situation had become more desperate as the Israelis reduced the permitted overflying time from 24 to nine hours a day. As a result, Macmillan again appealed directly to Eisenhower for support. He explained that the British troops in Jordan had only 12 days of food and oil supplies and only a few days of ammunition. He also reiterated the request put to Dulles for the Americans to take-over the airlift. ${ }^{89}$ The next day Eisenhower agreed; United States Air Force Globemasters would take-over the provision of supply. ${ }^{90}$ 
Macmillan had succeeded in his long held endeavour to secure a formal military relationship for the operation. ${ }^{91}$

Despite securing the airlift, Macmillan and Selwyn Lloyd continued to push for more military and logistical support with the ultimate hope of securing American boots on the ground to stand alongside British forces. On the day that the British operation began, Macmillan sent Selwyn Lloyd to Washington to meet with the State Department and White House to stress that the British were still hoping for American military participation. ${ }^{92}$ The memorandum of the conversation with Dulles records that Selwyn Lloyd declared, "the British by going into Jordan had put themselves in an extremely vulnerable position. He said he would feel much more certain of the security of the British position if the United States also had troops in Jordan." 93 In later speaking with Eisenhower, he re-emphasised his position, first by thanking the Administration for its support thus far and, then, adding, "This was all to the good but the British Government would be particularly happy if the Jordanian exercise could be a truly joint operation." 94 Eisenhower remained unconvinced and instead compared the Lebanon and Jordan operations to that of the division of effort over the Allied invasion of North Africa in 1942, an analogy well known to Macmillan. ${ }^{95}$ These words did not prevent Selwyn Lloyd from pushing one more time at the end of the meeting for American participation in Jordan, again to no avail.

Five days later Macmillan decided to try his personal touch to achieve the same objective. Stating fresh concerns about an impending coup, he appealed to Eisenhower from a military and political perspective: "I believe the essential thing is that you should send in some American troops to be alongside ours on the ground. Not only would this increase the military strength of the forces in Jordan, but it would have an extremely favourable political 
effect". ${ }^{96}$ This missive arrived at the same time as a similar telegram from Amman. On 20 July, King Hussein had stated to the press that he had asked for, and expected, American troops. The next day his prime minister, Samir al-Rifai, called the American ambassador to appeal for the despatch of 2,500 to 3,000 troops to Jordan. He dwelt on the negative impact of having only British troops and advised of the public concerns of re-occupation by British forces and the rising calls for general strikes in protest and demands for withdrawal. ${ }^{97}$ There followed the ambassador's approach to see Hussein-the King who, supported by the British ambassador, reiterated the request for American ground troops and an added appeal for air power. ${ }^{98}$ Whether a co-ordinated British-Jordanian endeavour manufactured these requests remains unknown. Regardless, it failed to have the desired effect; the counsellor of the American Embassy in Amman, Thomas Wright, reported to the State Department: "My opinion [is that] every argument advanced by Hussein and [the] British for United States troops is good reason we should stay out." 99 Eisenhower agreed and remained firm. He did not think it either wise or necessary to provide troops and used public opinion and difficulties with Congress as the scapegoat for the decision. ${ }^{100}$

These developments did not deter Macmillan, who continued to consider ideas on how to engage the Americans further to accelerate and formalise the re-building relationship. This process included the provision of American civilian technicians to maintain United States aircraft flying to Amman to provide the British with supplies. Also considered were ancillary forces to open up communications. ${ }^{101}$ Two weeks later, the Cabinet Defence Committee discussed further ideas including, perhaps controversially, asking Washington to charter merchant vessels to fly the American flag and bring supplies to the British down the 
Suez Canal. ${ }^{102}$ Macmillan also put in requests to Dulles for everything from the transport of drummed aviation fuel to maintenance of an airstrip and refrigerated containers. ${ }^{103}$

In addition, Macmillan succeeded in securing close co-operation at the military planning level. Prior to the sending of troops, the British and Americans set-up local operational liaison for their forces and planning liaison in London, with these relationships continuing throughout the Lebanon and Jordan campaigns. ${ }^{104}$ This military planning was particularly important for negotiating the joint withdrawal of forces - an endeavour pushed by Selwyn Lloyd to demonstrate a united Anglo-American operation and ensure not leaving British troops over-exposed. ${ }^{105}$ It also provided an existing forum for the British to develop further joint military planning used to consider on-going action in the wider Middle Eastern region after withdrawal. ${ }^{106}$

Throughout the operation, Macmillan also sought to secure continuing political and moral commitments. He and Selwyn Lloyd both worked hard to keep the Americans engaged throughout the campaign. Echoing the tone of Macmillan's phone conversation with Dulles the night before the start of the Jordan operation, management of the intervention ensured that Eisenhower's Administration felt constantly consulted and informed. It had the dual effect of increasingly inter-twining Washington within the operation and ensuring that "Operation Fortitude" would not repeat the secrecy and lack of understanding that cursed Anglo-Franco-Israeli operations in Suez. Eisenhower described his relationship with Macmillan at this time as being "in finger-tip communication". 107

During these communications, Macmillan was continuously at pains to stress that the British were not "going it alone" but, rather, that the United States and Britain were "in it together". Even without the existence of a joint mission, Macmillan continually took 
opportunities to emphasise to Eisenhower the importance of Anglo-American unity for the operation; and how their working together would continue into the future. On 18 July, he wrote to the president:

My great consolation is that we are together in these two operations in Lebanon and Jordan. We must at all costs not be divided now when we have been forced to play for such high stakes. I am sure that Foster and Selwyn will be able to work out together a joint plan for the future. ${ }^{108}$

He ended by stressing “our close and intimate cooperation together". Selwyn Lloyd agreed and emphasised that "it is desperately important" for the United States and Britain to keep together on Lebanon and Jordan. ${ }^{109}$

Macmillan also leveraged his relationship with Washington for diplomatic support in handling the UN and Russian responses to the intervention. ${ }^{110}$ All policy decisions came after full consultation with Washington. In a revealing telegram from London to the UN delegation in New York, the Foreign Office advised:

In continuing your discussions with the Secretary General[,] I hope you will take care to emphasise their informal, exploratory basis. Our present views are still tentative and until we have discussed them with the Americans[,] we do not want to give $\mathrm{Mr}$ Hammarskjold [the UN secretary general] the impression that they represent firm policy decisions. ${ }^{111}$

An informal working committee set-up within the British Embassy at Washington to coordinate issues specifically related to Jordan, including the UN negotiations, managed this liaison and negotiation. The committee met once a day and was described by Dulles as performing "an excellent job". 112 
Finally, Macmillan also used the Americans to help manage British economic realities. Not only did he have to pull the strings of the Eisenhower Administration, he also had to keep tight control on the strings of the British purse. During the Jordan crisis, he looked to achieve both by seeking a financial commitment from Washington to help with the operation. Again, Macmillan stressed this issue to Eisenhower from the outset of the operation via Hood: "The Prime Minister said that there was a great burden on the United Kingdom. There was already great pressure on the pound which meant a lot of money being spent to maintain its value . . . He hoped that the US Government understood this." "113 His efforts paid off. The United States provided economic assistance in a number of ways including funding the payment to the Shell Oil Company and British Petroleum for the initial supplies of oil to reach Aqaba. ${ }^{114}$ The Americans also took over the funding of the Jordanian Royal family and army - which had become increasingly too heavy a burden for the British, totalling around $\$ 40.5$ million per year - and earmarked $\$ 10$ million for Jordanian development. ${ }^{115}$ In comparison, the British only offered Jordan $£ 1$ million in budgetary aid and a similar amount in interest free development loans. ${ }^{116}$

Following the end of the Suez imbroglio, London identified two clear lessons for the future; Britain could no longer afford its position in the world; and it, therefore, would have to work with the Americans in all future interventions. Macmillan was privy to these lessons and had come to similar conclusions; but he saw that combining lessons learnt could benefit Britain in the long-term if Washington could be persuaded to support its ally politically, diplomatically, militarily, and economically. He wanted to be able to utilise American power to help Britain in areas that it could no longer afford to maintain, slowing down and managing British decline by bolstering British policy with American support. 
To achieve this aim, Macmillan searched for means to commit the United States to helping and working with the British. Even before rising to the premiership, Macmillan began efforts to re-build relations with Washington and, upon becoming prime minister, leveraged his personal connexions with Eisenhower to accelerate andthe revitalise good relations between the two Powers. He also sought to institutionalise the process, first, to make it harder for the Americans to withdraw support and, second, to send a clear message to the global community of the renewed strength of the Anglo-American special relationship. Achieving this commitment from Washington was a slow process with little effort from across the Atlantic and early disappointment when Eisenhower rejected British participation in the American operation in Lebanon.

However, the Jordan crisis provided a new and unique opportunity seized upon Macmillan. Although there were limits to what the Americans were prepared to offer, ${ }^{117}$ and Macmillan never achieved his ultimate ambition to make it a truly joint operation, he masterfully used the situation to his advantage and expanded American commitments of support as the operation progressed. Rather than demonstrating a subservient British foreign policy, the operation in Jordan revealed an active prime minister determined to use personal connexions and long-term allies for the benefit of Britain, pulling the strings of the Eisenhower Administration to achieve his own ends.

By the end of the campaign, it seemed as if Macmillan had managed a number of his objectives. He had proved to be a critical actor in returning the trans-Atlantic relationship to its pre-Suez state. Despite some initial tension, and-lingering resentment and suspicions on both sides, the Anglo-American alliance exited the Jordan operation stronger than it has entered. ${ }^{118}$ He also managed to negotiate a simultaneous rise of British prestige - through a 
successful return to the Middle East and decline in economic responsibility - by convincing the United States to take over much of the financial responsibility for Jordan. These actions are in stark opposition toby the orthodox claims of scholars about British subservience to American foreign policy after Suez. Instead, it reveals Macmillan as an agent of learning whoand managed change for British advantage.

\section{Notes}

Acknowledgement. I would like to thank Mr David Kettle, Professor John Young, Dr Andrew Mumford, members of the Centre for British Politics, and the anonymous reviewers for their helpful comments and advice. The Arts and Humanities Research Council funded this research.

${ }^{1}$ See for example, W. Scott Lucas, Britain and Suez: The Lion's Last Roar (Manchester, 1996); William Roger Louis, Ends of British Imperialism: The Scramble for Empire, Suez, and Decolonization (London, 2006).

2 Elizabeth Monroe, Britain's Moment in the Middle East 1914-1956 (London, 1963); Zach Levey and Elie Podeh, eds., Britain and the Middle East (Eastbourne, 2008). There is also a revisionist approach to this position dating back to John Darwin, Britain and Decolonisation: The Retreat from Empire in the Post-War World (Basingstoke, 1988).

${ }^{3}$ Dale to Parsons and Lister, "Memorandum: US Stake in Avoiding UK Financial Crisis", 26 November 1956, Department of State, Papers Relating to the Foreign Relations of the United States [hereafter FRUS] 1955-1957 (Washington, DC, on-going), Volume XXVII, Document 247,672 .

\footnotetext{
${ }^{4}$ Harold Macmillan, Riding the Storm: 1956-1959 (London, 1971), 175.
} 
5 John Dickie, Special No More: Anglo-American Relations - Rhetoric and Reality (London, 1994).

${ }^{6}$ Ibid. 511.

7 BBC News "How Macmillan shocked officials" (22 February 2005): news.bbc. co.uk/1/hi/uk_politics/4285909.stm.

${ }^{8}$ Macmillan, Storm, 199.

${ }^{9}$ See for example, David Dimbleby and David Reynolds, An Ocean Apart: The Relationship between Britain and America in the Twentieth Century (London, 1988); John Dumbrell, A Special Relationship: Anglo-American Relations in the Cold War and After (Basingstoke, 2001); Ritchie Ovendale, Anglo-American Relations in the Twentieth Century (Basingstoke, 1998); Nigel J. Ashton "Harold Macmillan and the 'Golden Days' of Anglo-American Relations Revisited, 1957-63”, Diplomatic History, 29/4(2005), 695-96.

${ }^{10}$ W. Scott Lucas, Divided We Stand: Britain, the US and the Suez Crisis (London, 1991); Ritchie Ovendale, Britain, the United States and the Transfer of Power in the Middle East (Leicester, 1996).

${ }^{11}$ Simon C. Smith, Ending Empire in the Middle East: Britain, the United States and PostWar Decolonization, 1945-73 (London, 2012); idem., “'America in Britain's place?’: AngloAmerican relations and the Middle East in the aftermath of the Suez crisis", Journal of Transatlantic Studies, 10/3(2012), 252-70.

12 Nigel Ashton, Eisenhower, Macmillan and the Problem of Nasser (Basingstoke, 1996); idem., "'A Great New Venture?' Anglo-American Cooperation in the Middle East and the Response to the Iraqi Revolution, July 1958”, Diplomacy \& Statecraft, 4/1(1993), 58-89. 
${ }^{13}$ There is little literature focused exclusively on this intervention but see Stephen Blackwell, British Military Intervention and the Struggle for Jordan: King Hussein, Nasser and the Middle East Crisis, 1955-1958 (London, 2009); Lawrence Tal, "Britain and the Jordan Crisis of 1958", Middle Eastern Studies, 31/1(1995), 39-57. Others have analysed the operation in conjunction with other events: Nigel John Ashton “A Microcosm of Decline: British Loss of Nerve and Military Intervention in Jordan and Kuwait, 1958 and 1961”, Historical Journal, 40/4(1997), 1069-83; idem., “'A 'Special Relationship' sometimes in spite of ourselves': Britain and Jordan 1957-1973", Journal of Imperial and Commonwealth History, 33/2(2005), 221-44; Ritchie Ovendale, "Great Britain and the Anglo-American Invasion of Jordan and Lebanon in 1958", International History Review, 16/2(1994), 284-303; Ivan Pearson "The Syrian Crisis of 1957, the Anglo-American 'special relationship' and the 1958 landings in Jordan and Lebanon”, Middle Eastern Studies, 43/1(2007), 45-64.

${ }^{14}$ Operation Fortitude is seen as the first "new" intervention; the British were involved in an intervention in Oman in 1957 but were already occupying parts of the country.

${ }^{15}$ Cabinet Conclusion [CC], 59(58), 16 July 1958, CAB [Cabinet Office Archives, The National Archives, Kew] 128/32.

${ }^{16}$ Harold Macmillan on working with the Americans on the eve of Operation Fortitude, quoted in The Spectator (18 July 1958).

${ }^{17}$ House of Commons Debates, Hansard (22 November 1956), Volume DLX, 1932, 22; Ibid., (22 March 1960), Volume DCXX, 231. A number of other reasons emerged. For example, Butler [Conservative leader, House of Commons], Ibid., (22 November 1956), Volume DLX, 1932, 22; Macmillan, Ibid., (22 March 1960), Volume DCXX, 231; Brook [Cabinet secretary] memorandum "B" to Macmillan, 5 March 1959, PREM [Prime 
Minister's Office Archives, The National Archives, Kew] 11/2653; Reid to Trend [deputy secretary, Cabinet], 9 May 1966, CAB 103/598; Cabinet Office to Crossman [senior Labour Party MP], 14 November 1965, CAB 165/109.qq

${ }^{18}$ For an excellent summary, see Peter Beck “'The Less Said about Suez the Better': British Governments and the Politics of Suez's History, 1956-67", English Historical Review, 124/508(2009), 605-40.

${ }^{19}$ See for example, Millard [Macmillan's private secretary], 21 October 1957, FO [Foreign Office Archives, The National Archives, Kew] 800/728; The Executive Committee of the Army Council, nd, WO [War Office Archives, The National Archives, Kew] 32/16731; War Office minutes, 29 January 1957, WO 32/21899/8A; Eden, 28 December 1956, PREM 11/1138.

${ }^{20}$ General Sir Charles Keightley "Despatch on operations in the Eastern Mediterranean November - December 1956: Part II Certain Specific Recommendations”, 11 October 1957, DEFE [Ministry of Defence files, The National Archives, Kew, London] 11/137, 4.

21 Ibid.

${ }^{22}$ Discussions took place 31 October 1957 and 6 February 1958. Confidential annex to $\operatorname{COS}(58) 12^{\text {th }}$ meeting, DEFE $11 / 137$.

${ }^{23}$ The Chief of the Imperial General Staff was ordered to withdraw all circulated copies of the despatch. Loose minute 51/0143/5729(SD7B), 3 May 1957, WO 32/21899/10A.

${ }^{24}$ Millard, "Memorandum on relations between the United Kingdom, the United States and France in the months following Egyptian nationalisation of the Suez Canal Company in 1956”, 21 October 1957, FO 800/728.

${ }^{25}$ Ibid., 29. Emphasis added. 
${ }^{26}$ Ibid. Emphasis added.

${ }^{27}$ Eden, 28 December 1956, PREM 11/1138.

${ }^{28}$ Foreign Affairs Steering Committee, "British Obligations Overseas", 14 April 1958, FO $371 / 135611$.

${ }^{29}$ Ibid.

${ }^{30}$ Ibid., 3 .

${ }^{31}$ Ibid., 12.

${ }^{32}$ Meeting Record of the Conservative Parliamentary Foreign Affairs Committee, 9 July 1958 [Conservative Party Archive, Bodleian Library, Oxford].

${ }^{33}$ Ashton “"Golden Days”, 697-98.

${ }^{34}$ Harold Evans, Downing Street Diary: The Macmillan Years (London, 1981).

${ }^{35}$ Kevin Ruane and James Ellison, "Managing the Americans: Anthony Eden, Harold Macmillan and the Pursuit of 'Power-by-Proxy' in the 1950s", Contemporary British History, 18/3(2004), 147-67.

36 "Memorandum for the Record by the Secretary of State", FRUS 1955-1957, Volume XXVII, Document 249, 677.

${ }^{37}$ Dwight D. Eisenhower, Waging Peace, (New York, 1965), 120.

${ }^{38}$ Ibid., 212; Memorandum of a Conversation, Mid-Ocean Club, Bermuda, 21 March 1957, FRUS 1955-1957, Volume XXII, Document 270.

39 Bureau of European Affairs, "Position Paper", 13 February 1957, FRUS 1955-1957, Volume XII, 694.

${ }^{40}$ Eisenhower, Waging Peace, 122. 
41 “Memorandum of a Conversation”, 21 March 1957, FRUS 1955-1957, Volume XII, 710$11,716$.

${ }^{42}$ Merchant "Memorandum" to the Secretary of State, 19 October 1957, FRUS 1955-1957, Volume XXVII, Document 309.

43 Department of State, "Memorandum of a Conversation", 18 October 1957, FRUS 19551957, Volume XXVII, Document 308. A number of scholars have emphasised the importance of these two conferences for re-establishing the Anglo-American "special relationship". See for example, Michael Dockrill, "Restoring the 'Special Relationship': The Bermuda and Washington Conferences, 1957', in Dick Richardson and Glyn Stone, eds., Decisions and Diplomacy (London, 1995), 205-23; Margaret Gowing, "Nuclear Weapons and the 'Special Relationship'”, in William Roger Louis and Hedley Bull, eds., The Special Relationship: Anglo-American Relations Since 1945 (Oxford, 1986).

${ }^{44}$ See for example, Department of State, "Memorandum of a Conversation", 25 October 1957, FRUS 1955-1957, Volume XXVII, Document 328 and 329.

${ }^{45}$ For more, see Matthew Jones “Anglo-American relations after Suez, the rise and decline of the working group experiment, and the French challenge to NATO, 1957-59", Diplomacy \& Statecraft, 14/1(2003), 47-79.

${ }^{46}$ CC, 28 October 1957, CAB 128/31.

${ }^{47}$ Washington to FO, 8 November 1957, PREM 11/2521.

${ }^{48}$ Memorandum of a conversation, White House, 13 May 1958, FRUS 1958-1960, Volume XI, Document 30.

49 Memorandum of a conversation between Dulles and Caccia, 21 May 1958, FRUS 19581960, Volume XI, Document 45. 
${ }^{50}$ Decker [Middle East Planning Committee, Joint Chiefs of Staff] "Memorandum" to Burke [chief, Naval Operations] 19 May 1958, FRUS 1958-1960, Volume XI, Document 42.

${ }^{51}$ Richard V. Damms, "In Search of 'Some Big, Imaginative Plan': The Eisenhower Administration and American Strategy in the Middle East after Suez", in Simon C. Smith, ed., Reassessing Suez 1956 (Aldershot, 2008), 186.

${ }^{52}$ Special National Intelligence Estimate, "Consequences of Possible US Courses of Action Respecting Lebanon", 5 June 1958, SNIE 36.4-58, FRUS 1958-1960, Volume XI, Document 60.

${ }^{53}$ Laskey to Bishop, 3 April 1958, FO 371/132330.

${ }^{54}$ Tal "Jordan Crisis", 42; Uriel Dann, King Hussein and the Challenge of Arab Radicalism: Jordan 1955-1967 (Oxford, 1991), 81-82.

${ }^{55}$ Minutes of Cabinet Defence Committee meeting, 14 July 1958, CAB 131/19. ${ }^{56}$ Ibid.

${ }^{57}$ Eisenhower, Waging Peace, 272.

${ }^{58}$ Macmillan, Storm, 511.

${ }^{59}$ Ibid.

${ }^{60}$ Ibid., 512.

${ }^{61}$ Mason to FO, 14 July 1958, PREM 11/2380/322.

${ }^{62}$ Minutes of Cabinet Defence Committee meeting, 14 July 1958, CAB 131/19.

${ }^{63}$ Minutes of Cabinet Defence Committee meeting, 15 July 1958, CAB 131/20.

${ }^{64}$ The UN was paralysed at this time by Cold War politics. FO to Washington, 15 July 1958 , PREM 11/2380/314; FO to Amman, 16 July 1958, PREM 11/2380/280; FO to Amman, nd, PREM 11/2380/296. 
${ }^{65}$ Macmillan to Eisenhower, 14 July 1958, FRUS 1958-1960, Volume XI, Document 172;

FO to Washington, 15 July 1958, PREM 11/2380/314.

${ }^{66}$ Macmillan to Eisenhower, memorandum of a telephone conversation, 14 July 1958, FRUS 1958-1960, Volume XI, Document 131.

${ }^{67}$ Eisenhower, Waging Peace, 273.

${ }^{68}$ Macmillan, Storm, 514.

${ }^{69}$ The British ambassador at Amman, Charles Johnston, denied vociferously this assessment. See Charles Johnston, The Brink of Jordan (London, 1972), 108.

${ }^{70}$ Memorandum of a telephone conversation between Macmillan and Dulles, 16 July 1958, FRUS 1958-1960, Volume XI, Document 184.

${ }^{71}$ Record of a telephone conversation between Macmillan and Hood [chargé d'affaires, Washington], 15/16 July, PREM 11/2388/195; Hood to FO, 18 July 1958, PREM 11/2388/103.

${ }^{72}$ Macmillan, Storm, 514.

${ }^{73}$ Wilson to Macmillan, “Military Assistance to Jordan”, 16 July 1958, PREM 11/2380/292.

${ }^{74}$ Memorandum of a telephone conversation between Macmillan and Dulles, 16 July 1958, FRUS 1958-1960, Volume XI, Document 182.

${ }^{75}$ Record of a telephone conversation between Macmillan and Dulles, 17 July 1958, PREM $11 / 2380 / 269$.

${ }^{76}$ Memorandum of a telephone conversation between Macmillan and Dulles, 16 July 1958, FRUS 1958-1960, Volume XI, Document 184.

${ }^{77}$ Hood telegram to FO, 17 July 1958, PREM 11/2380/272.

${ }^{78}$ FO to Amman, 17 July 1958, PREM 11/2380/268. 
${ }^{79}$ Minutes of Cabinet Defence Committee, 14 July 1958, CAB 131/19.

${ }^{80}$ Tal, "Jordan Crisis", 45.

${ }^{81}$ Salt to FO, 17 July 1958 , FO 371/134345.

${ }^{82}$ Macmillan, Storm, 519-20.

${ }^{83}$ Eisenhower, Waging Peace, 279.

${ }^{84}$ Memorandum of a conversation, 19 July 1958, FRUS 1958-1960, Volume XI, Document 202.

${ }^{85}$ Minutes of Cabinet Defence Committee, 20 July 1958, CAB 131/20.

${ }^{86}$ Ibid.

${ }^{87}$ Ibid.

${ }^{88}$ Author unknown, nd, AIR [Air Ministry Archives, The National Archive, Kew] 8/2214.

${ }^{89}$ Macmillan to Eisenhower, 22 July 1958, FRUS 1958-1960, Volume XI, Document 214.

${ }^{90}$ Eisenhower, Waging Peace, 282.

${ }^{91}$ Ibid., 281; Hood to FO, 19 July 1958, PREM 11/2388/103.

${ }^{92}$ Hood to FO, 18 July 1958, FO 371/133823.

${ }^{93}$ Memorandum of a conversation, 17 July 1958, FRUS 1958-1960, Volume XI, Document 187.

${ }^{94}$ Ibid., 188.

${ }^{95}$ Ibid.

${ }^{96}$ Macmillan to Eisenhower, 22 July 1958, Ibid., Document 214.

${ }^{97}$ Amman to Washington, 21 July 1958, Ibid.,, Document 211.

${ }^{98}$ Amman to Washington, 22 July 1958, Ibid., Document 212.

${ }^{99}$ Ibid. 
${ }^{100}$ Eisenhower, Waging Peace, 281, 282.

${ }^{101}$ Cabinet Defence Committee Minutes, 24 July 1958, CAB 131/20/35.

${ }^{102}$ Cabinet Defence Committee Minutes, 6 August 1958, CAB 131/20/42.

${ }^{103}$ Macmillan to Dulles, Aide-Memoire, 27 July 1958, PREM 11/2380/51.

${ }^{104}$ Hood to FO, 17 July 1958, PREM 11/2380/237; Record of a luncheon meeting, 27 July 1958, PREM 11/2399/31.

${ }^{105}$ London to Washington, 11 August 1958, FRUS 1958-1960, Volume XI, Document 265.

${ }^{106}$ Chiefs of Staff Committee, 15 September 1958, DEFE 5/84/199.

${ }^{107}$ Eisenhower, Waging Peace, 279.

${ }^{108}$ Macmillan to Eisenhower, 18 July 1958, FRUS 1958-1960, Volume XI, Document 193.

${ }^{109}$ London to Washington, 11 August 1958, Ibid., Document 265.

${ }^{110}$ For an overview of the Russian difficulties, see Eisenhower, Waging Peace, 283-85; CC, 22 July 1958, CAB 128/32. On handling the UN, see "Record of a meeting at the State Department”, 17 July 1958, FO 371/133823; Nigel De Lee “'More like Korea than Suez': British and American intervention in the Levant in 1958", Small Wars and Insurgencies, 8/3(1997), 16. For a discussion on both, see Record of a Meeting, 27 July 1958, PREM $11 / 2380 / 52$.

${ }^{111}$ FO to New York, 2 August 1958, PREM 11/2380/20.

${ }^{112}$ Dulles to Macmillan, 1 August 1958, PREM 11/2399/20.

${ }^{113}$ Record of a telephone conversation between Macmillan and Hood, 15 July 1958, PREM 11/2388/196.

${ }^{114}$ Jarratt to Bishop, 18 July 1958, AIR 20/10110. 
${ }^{115}$ Robert V Keeley, Association for Diplomatic Studies and Training Foreign Affairs Oral History Project: adst.org/oral-history/, 17-18.

116 Johnston, Brink of Jordan, 109.

117 For example, Hood requested American support if the Egyptians prevented passage of British troops through the Suez Canal to Jordan. Dulles could not agree. Memorandum of a conversation, 3 August 1958, FRUS 1958-1960, Volume XI, Document 250.

${ }^{118}$ Eisenhower wrote to Macmillan stating as much. Eisenhower to Macmillan, 3 November 1958, PREM 11/3028. 